\title{
Georadar investigations to detect cavities in a historical town damaged by an earthquake of the past
}

\author{
F. T. Gizzi ${ }^{1}$, A. Loperte ${ }^{2}$, A. Satriani ${ }^{2}$, V. Lapenna ${ }^{2}$, N. Masini ${ }^{1}$, and M. Proto ${ }^{2}$ \\ ${ }^{1}$ Istituto per i Beni Archeologici e Monumentali (IBAM)-CNR- Potenza, Italia \\ ${ }^{2}$ Istituto per le Metodologie di Analisi Ambientale (IMAA)-CNR- Potenza, Italia
}

Received: 23 October 2009 - Revised: 18 December 2009 - Accepted: 2 February 2010 - Published: 9 March 2010

\begin{abstract}
This paper aims to highlight the use of the georadar as a useful prospecting technique to identify the areal density and the geometrical features of the grottoes placed in a historical town characterised by high seismic hazard.

The town considered here is Rionero in Vulture (Southern Italy) that was hit by several historical earthquakes, among which the 1930 Irpinia earthquake (Me=6.7, Is=VIII MCS).

For this event a damage map was already available from a previous study (Gizzi and Masini, 2006). This map shows that some sectors of the town suffered higher damage. One factor causing the uneven distribution of the effects is considered to be the presence of grottoes.

To strengthen this work hypothesis it was necessary to indepth investigate the subsoil of Rionero in Vulture. Therefore, geophysical data were correlated and integrated with data obtained from field surveys and historical documentary sources. All these investigations allowed to obtain more insights about the influences of the man-made caves on seismic damage.
\end{abstract}

\section{Introduction}

It is well known that subsoil features can strongly change the seismic effects on buildings, causing an increase of damage. Among causes that can bring about the differential effects, the stability of foundation subsoil during seismic shaking is of great importance. From this point of view, the presence of underground voids in urban areas needs to be thoroughly considered. Both natural cavities (mainly of karst origin) and man-made ones (frequently dug in volcanic deposits) are

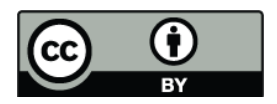

Correspondence to: F. T. Gizzi (f.gizzi@ibam.cnr.it) present in downtown area of many cities over the world such as Mexico City, Rome, Nottingham, New Orléans, Naples, Palermo, and Catania.

Starting from these preliminary remarks, the work presented here aims to investigate the role played by grottoes in increasing the seismic effects in an urban context. The site under investigation is Rionero in Vulture, a site characterised by both hundreds cavities and high seismicity. For this town, a highly-detail map of seismic damage caused by the 1930 Irpinia earthquake $(\mathrm{Me}=6.7$, Is=VIII MCS) was already available (Gizzi and Masini, 2006).

To infer the role played by cavities during the seismic shaking it is fundamental to identify both the density and the geometrical features of the grottoes. To this purpose, geophysical investigations integrated by site surveys were carried out. In detail, four georadar prospecting in the area of Rionero that suffered highest damage for the 1930 earthquake were carried out. Taken together, these data allowed to obtain more insights about the influences of the man-made caves on seismic damage.

The choice of georadar as a technique for investigating the underground cavities was driven both by logistical considerations about the execution of the surveys and by considerations about the geological features of the site.

As concern the first aspect, an advantage of the georadar technique consists in the fact that electrodes do not need to be put in the soil. This allows to save many time and to investigate sectors of the urban area otherwise hard to survey for logistical constraints (e.g. road traffic).

As regards the site features, the use of the georadar in this context was thought to be suitable considering that the supposed air-filled or water-saturated backfilling voids represent significant radar reflectors compared to the geological properties of the subsoil.

Published by Copernicus Publications on behalf of the European Geosciences Union. 


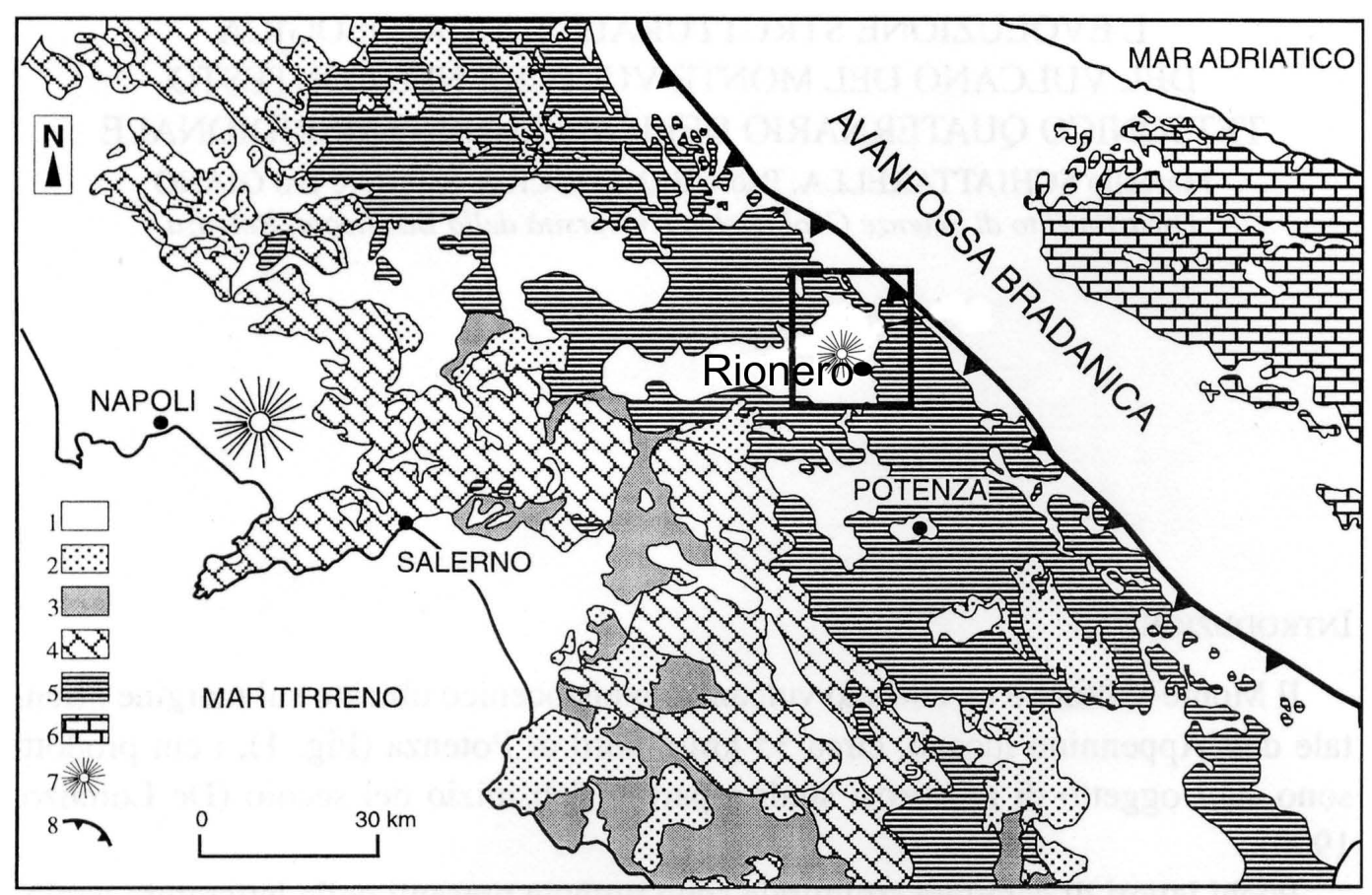

Fig. 1. Tectonic outline of the southern Apennines. 1=Bradanic foredeep and intrapenninic sediments. Volcanoclastic rocks (plio-quaternary); 2=Sinorogenic sediments (Miocene); 3=Liguride complex (Cretaceous-Oligocene); 4=Apennine plataform carbonate (Mesozoic-Cenozoic); 5= Lagonegro basin sediments (Trias-Miocene); 6=Apulian plataform sediments (Trias-Pliocene); 7=Volcanoes; $8=$ Buried allochthonous front. Vulture area is shown from the rectangle (from Pescatore et al., 1999, modified).

Georadar prospecting method has already proved to be a very useful tool for detecting the location and the geometry of the underground cavities in urban and in nonurbanised areas characterised by different geological settings (e.g. Ulugergerli and Akca, 2006; Mochales et al., 2008; Wadhwa et al., 2008). By this study, we hope to meaningfully add to the body of knowledge about the seismic behaviour of such sites and, thereby, of identifying potentially "weak" urban zones can be so that suitable prevention strategies can be implemented to preserve the historical centre.

\section{Geological setting of the study area}

The study area is located close to the extinct Vulture volcano, in Southern Apennines (Fig. 1). This chain is a Neogene fold and thrust belt that is made up of a buried carbonate duplex system tectonically overlain by NE verging thrust sheets (Mostardini and Merlini, 1986; Patacca and Scandone, 1989; Lentini et al., 1996) made-up of Mesozoic-Paleogene sediments laid in platform and basin paleogeographic domains.

These were involved in the contractional episodes since the late Oligocene-early Miocene times (Pescatore et al., 1999). Since Pliocene to Quaternary, extensional tectonics progressively replaced the compressional field. During the Middle Pleistocene, the most recent chain deformation oc- curred on its southern and easternmost portion (Scandone et al., 1992) and the history of strato-volcano Vulture had its beginning.

The products of Vulture are composed of highly undersaturated alkaline-potassic to ultrapotassic rocks such as foidites, tephrites, phonolites, trachites (Giannandrea et al., 2006) with age ranging from $0.674 \pm 7$ to $0.132 \pm 12 \mathrm{ka} \mathrm{Be}-$ fore Present (Brocchini et al., 1994). Recently, the volcanic products have been grouped in two supersynthemes: Vulture Mount and Monticchio ones (Schiattarella et al., 2005; Giannandrea et al., 2006). Rionero in Vulture is situated in this geographic-geological background. In detail, in the town examined here pyroclastic products belonging to Vulture Mount supersynthem outcrop.

One peculiarity of the towns surrounding Vulture Mount, included Rionero, is the presence of hundreds of man-made caves dug in pyroclastic deposits. These grottoes overlap on several topographic levels. Cave density is usually high in the quarters on steep slopes. Grottoes are both below and at the same topographic level as the buildings with a broad planimetrical extension, which are also beneath the streets. Nowadays, the caves are used for storage or as wine cellars and stables. 


\section{The 23 July 1930 earthquake in Rionero in Vulture}

In about eight centuries, the Vulture area has experienced at least ten earthquakes felt with a site intensity Is $\geq$ VI MCS. Among these historical events, seven hit the town analysed here.

The last significant event that affected the area investigated was on 23 July 1930. It is the Irpinia earthquake whose epicentral intensity (Io) and magnitude (Me) have been, respectively evaluated as $\mathrm{X}$ in Mercalli-Cancani-Sieberg scale and 6.7 (Boschi et al., 2000).

The event hit at 00:08 GMT an area of about $6.500 \mathrm{~km}^{2}$. It caused heavy damage to the territory ranging from Melfi to Ariano Irpino, killed 1404 people and caused very deep damage to private and public buildings.

As regards the earthquake effects on the population of Rionero, they can be summarized in 25 dead. Moreover, the event caused heavy losses of private and monumental buildings.

In order to reconstruct the damage "scenario" for Rionero, expert unpublished technical-administrative documentation produced by the Genio Civile (Civil Engineers) supplemented by sources taken from web sources were analysed (Gizzi and Masini, 2006; Gizzi, 2009).

Observing the damage pattern (Fig. 2) it emerges that higher effects were concentrated within five areas: Rione Costa, which is the most affected quarter, Rione dei Morti in the central-southern part of the town, Rione Calvario, $R i$ one Piano delle Cantine and the area close to Mother Church in the northern area.

A cross-correlated analysis of the historical data suggest that the distribution of the damage can not be attributed only to the building vulnerability. Therefore, it is important to analyse how the geological features of the town and/or human intervention on urban territory influenced the damage. This also considering that coeval surveys indicate in grottoes the main cause of the uneven effects.

To address this point, georadar investigations and field surveys were performed. In detail, geophysical surveys were addressed in Rione Costa, the quarter where the highest damage was registered during the 1930 earthquake.

\section{Ground penetrating radar survey}

Ground penetrating radar (GPR) is a geophysical technique for shallow investigations with high resolution which has undergone a rapid development during the last two decades (Blindow and al., 1987). GPR methods measure the travel time of an electromagnetic wave transmitted from a transmitter antenna, reflected from the subsurface, and received via receiver antenna. The principles of the GPR method have been described extensively in the literature (Morey, 1974; U1riksen, 1982; Davis and Annan, 1989).
GPR has been used increasingly and accepted for geological, engineering, environmental (Loperte et al., 2004; Piscitelli et al., 2007) and archaeological science starting from the 1980s. In fact, it offers very high performances in terms of non invasivity, real time information and available spatial resolution thanks to the use of a easy and portable instrumentation able to perform measurements in an easy and fast way (Daniels, 1996, Lazzari et al., 2006).

A SIR 2000 Radar System matched to a monostatic antenna of $400 \mathrm{MHz}$ central frequency was used to accomplish the survey. The data were acquired in continuous mode. The acquisition time range was $140 \mathrm{~ns}$.

The GPR data set was analysed using the REFLEX- Win Version 5.0.5 program (Sandmeier, 2001).

Standard data processing has the aim to improving the "imaging" by correctly locating and focussing all the reflectors. It was performed through different steps. The first step was the trace removal to eliminate the ends of the radargrams when the antenna was not dragged.

Then, a zero time correction removed the propagation path of the signal within the cable and antenna. The third step was the gain removal and the energy decay compensation to restore a correct amplitude along each wavelet. A bandpass frequency filter with cut-off frequencies was set to reduce the noise at high and low frequencies. Subsequently, the background removal eliminated all the reflections that are not spatially varying along the direction of antenna's movement. Then, a Kirchhoff migration was performed by using a constant velocity of $0.05 \mathrm{~m} / \mathrm{ns}$ obtained by the hyperbolas adaptation. Finally, an envelope function was needed to show the results in terms of instantaneous amplitude of the processed signal. The result of the standard data processing is shown in Figs. 3 to 6.

\subsection{GPR results}

As indicate above, four georadar surveys were addressed in Rione Costa, the quarter where highest damage was registered during the 1930 earthquake. This area was selected whereas both on site surveys and historical documents indicated this zone have the highest number of grottoes.

The four GPR-profiles comprising about $700 \mathrm{~m}$ of linear survey were obtained, of these the most relevant radar sections will be shown.

The SN1 GPR-section, $37 \mathrm{~m}$ long, shows two hyperbolic anomalies between 18 and $28 \mathrm{~m}$ related to cavities. As shown in Fig. 3, the cavities, placed at 0.8 and $1 \mathrm{~m}$ deep, respectively, are about 5 and $4 \mathrm{~m}$ wide.

Moreover, the shallow part is characterized by many hyperbolic reflectors, between 0 and $8 \mathrm{~m}$ and between 21 and $35 \mathrm{~m}$, caused by the presence of wire mesh. Horizontal layer at $1.6 \mathrm{~m}$ depth is also shown. The lower part of GPR-section shows the presence of an absorbing area, probably correlated to the presence of water saturated soil. 


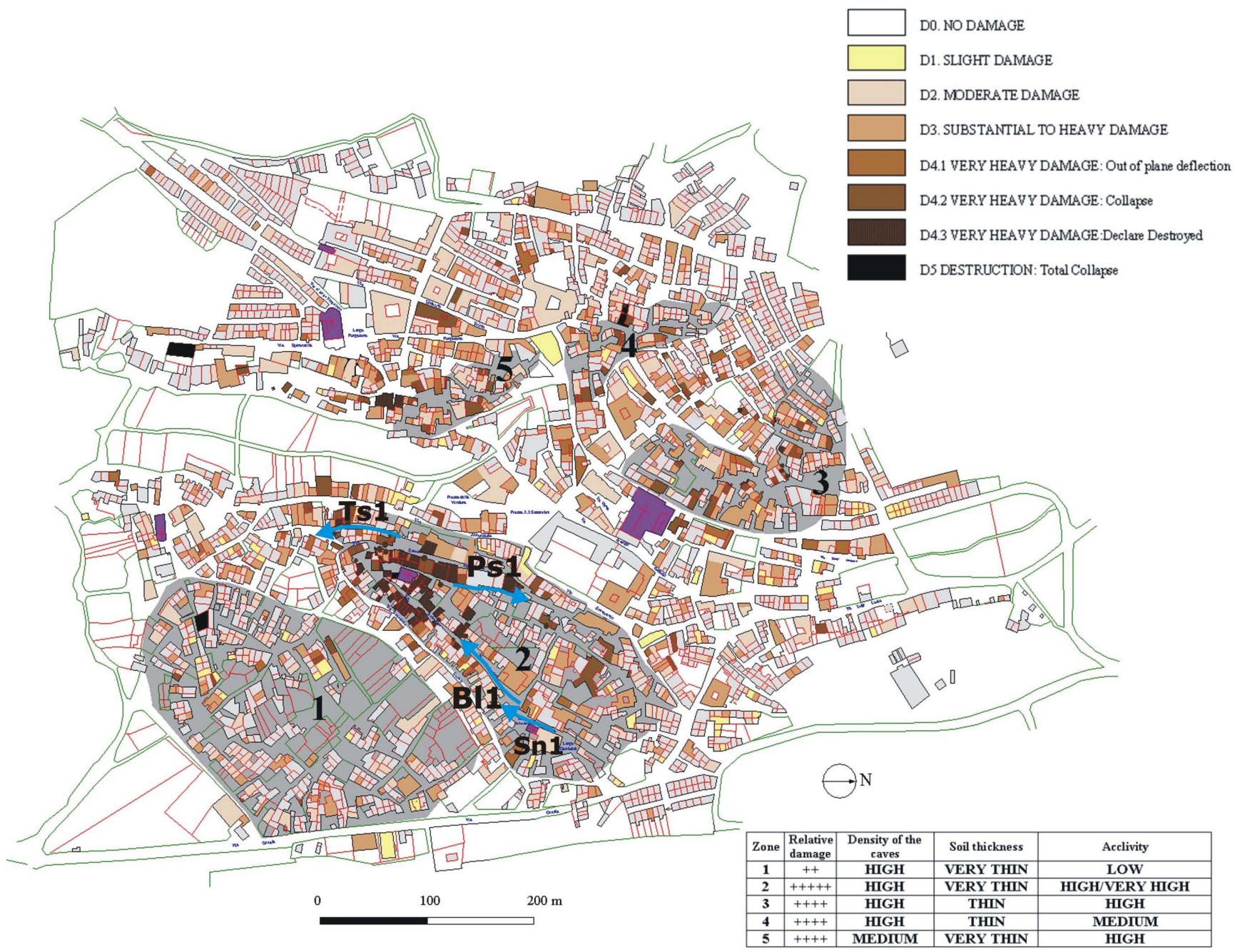

Fig. 2. Damage "scenario" for Rionero in Vulture as delineated by the analysis of historical sources (degree of damage is given in EMS-98 scale, Grunthal, 1998). The figure also shows the areas in which the caves are localized. At the bottom right-corner a table reports some features of these areas that seem suggest a key role in producing a local increase of damage. Profiles of georadar investigations are also indicated (Ts1=Trieste street; Ps1= Pisacane street; B11= Belvedere street; Sn1=San Nicola street).

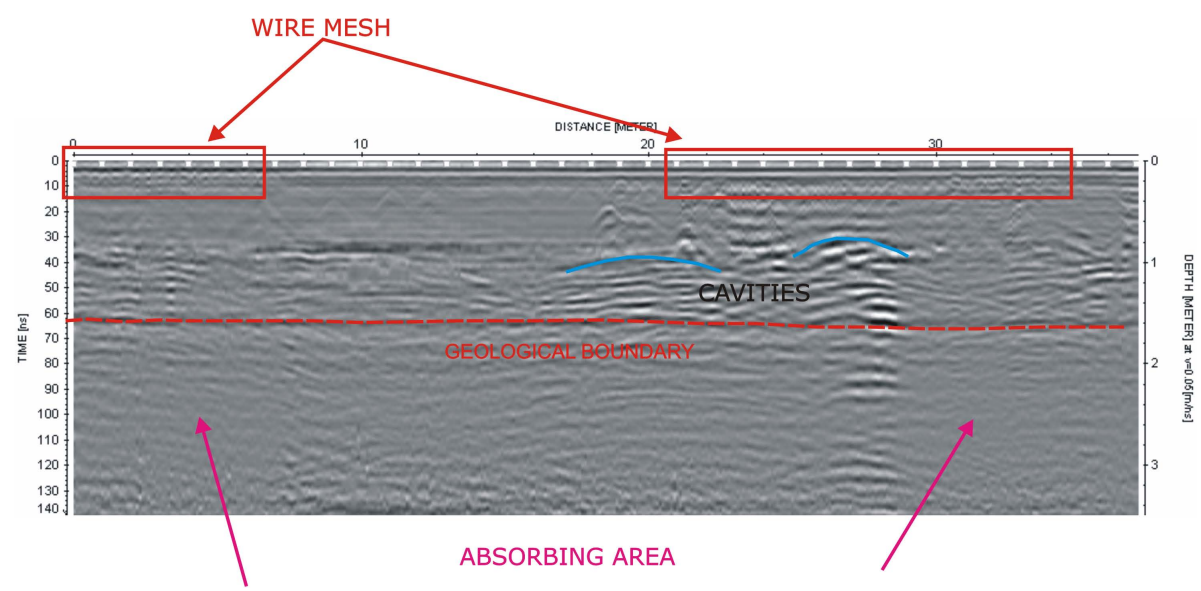

Fig. 3. SN1 georadar profile carried out along San Nicola street. 


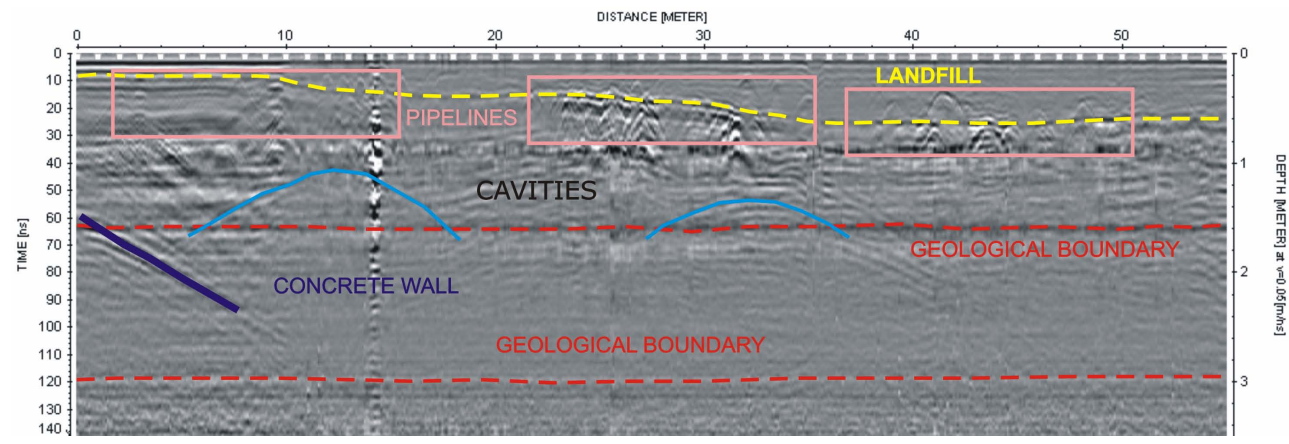

Fig. 4. BL1 georadar profile carried out along Belvedere street.

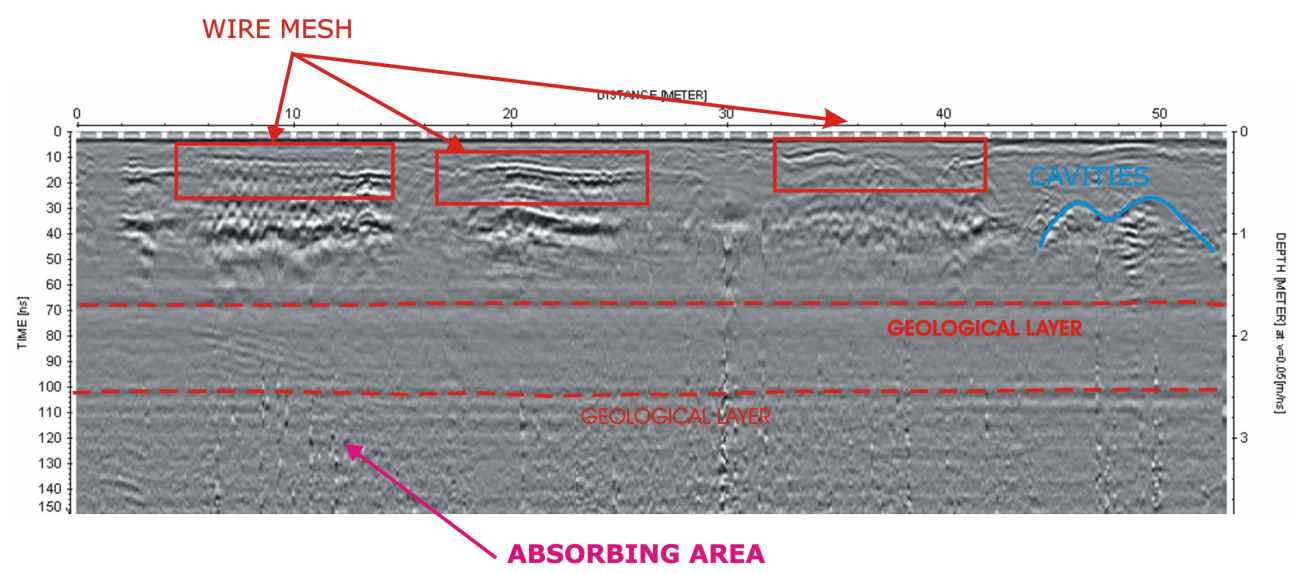

Fig. 5. PS1 georadar profile carried out along Pisacane street. They are also shown the geological layers that site surveys indicate as a succession of pumices and ashes.

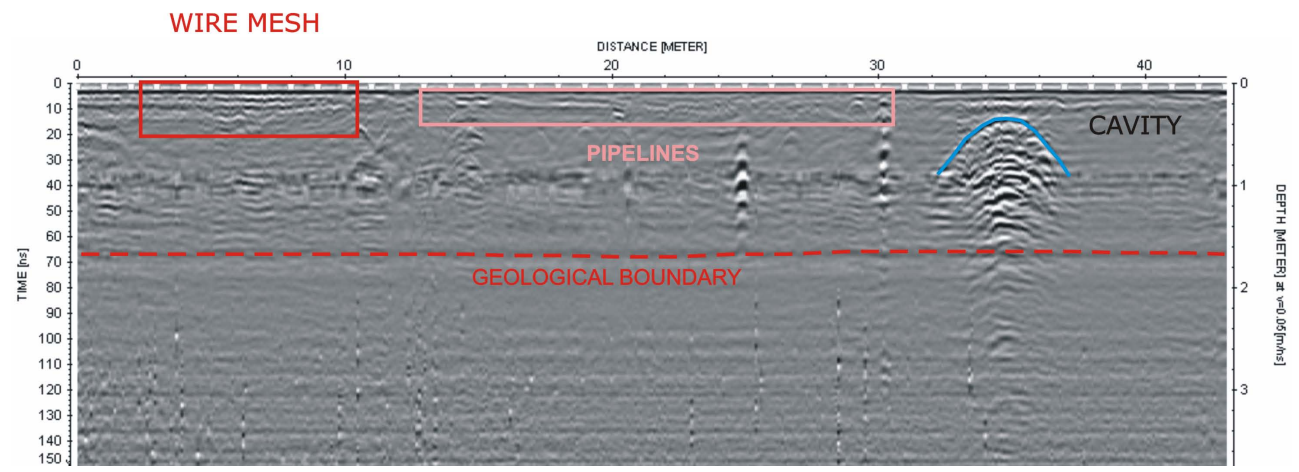

Fig. 6. TS1 GPR carried out along Trieste street. 
BL1 GPR-section, is $55 \mathrm{~m}$ long and is characterized by hyperbolic anomalies associated with the presence of cavities, located between 7 and $14 \mathrm{~m}$ at a depth of about $1 \mathrm{~m}$ and between $28 \mathrm{~m}$ and $34 \mathrm{~m}$ at a depth of about $1.2 \mathrm{~m}$ from the origin of the profile (Fig. 4).

Furthermore, this section shows a surface layer which tends to deepen to about $1 \mathrm{~m}$ and two nearly horizontal layers at 1.6 and $3 \mathrm{~m}$.

The lower part of GPR-section shows the presence of an absorbing area, probably related to the presence of water saturated soil.

Finally, throughout the section we observe the presence of pipelines identifiable by reflections hyperbolic surface.

The PS1 radar section is $53 \mathrm{~m}$ long (Fig. 5). In particular, the right side of electromagnetic section is, instead, characterized by two hyperbolic reflectors related to air filled cavities. For these cavities, placed at a depth of about $0.7 \mathrm{~m}$ and with a total width of about $8 \mathrm{~m}$ has been possible to do an inspection which confirmed the georadar data.

Figure 6 shows a GPR section characterized by an evident shallow ( $0.4 \mathrm{~m}$ depth) air filled cavity between 32 and $37 \mathrm{~m}$.

Moreover, the shallow part is characterized by many hyperbolic reflectors determinate of the presence of wire mesh between 7 and $25 \mathrm{~m}$.

As the previous GPR section, also the PS1 section shows two layers at different depth, 1.6 and $3 \mathrm{~m}$, and the lower part of GPR-section with an absorbing area, probably related to the presence of water saturated soil.

Moreover, the superficial part presents many hyperbolic reflectors determined by underground structures, like wire mesh and pipelines. At a depth of $1.6 \mathrm{~m}$ a horizontal geological layer is evident as in the previous radargram sections.

\section{The role of cavities on building damage}

According to georadar investigations and site surveys, Fig. 2 shows the main urban areas of the downtown (1-5) in which the grottoes are located, whereas data reported in the figure indicate some main features of the zones, such as the damage degree, the cave density, the soil thickness above the grottoes and the ground acclivity.

Analysing these data, it can be seen that the combination of three factors (density of the caves, soil thickness and acclivity) at the top of the variation range caused the highest damage (Rione La Costa [zone 2]) whereas the combination of the same factors at intermediate level caused higher damage (zone 3-4-5). Even if only one factor belongs to the lowest class of the range, a decrease of damage is evident (Zone 1).

On the whole, the analysed data suggest that the widespread grottoes played a key role in producing a local increase of damage due to a mutual relationship between the buildings and the grottoes.
To strengthen this hypothesis, it should be emphasized that the caves show a prevalence of medium-high size with numerous joints in the pyroclastic deposits where they were dug. These features are further predisposing factors for the seismic instability of the building-soil system.

Another increased damage factor can be found in Rione Costa and Rione dei Morti. In these quarters, historical written sources refer that some buildings were founded on made land therefore during the earthquake possible consolidation phenomena with consequent differential sinking of the foundation soil took place. Georadar surveys show that landfill has a variable thickness $(0-1.5 \mathrm{~m})$ due to the need to level the soil.

On the whole, the analysed data suggest that the widespread grottoes played a key role in producing a local increase of damage due to a mutual relationship between the buildings and the grottoes.

\section{Conclusions}

Taking as a starting point the analysis of the causes of the uneven damage caused by an earthquake of the past in a historical town of Southern Italy, this paper has discussed about the utility of the georadar investigations to detect underground voids in an urban area. Indeed, based on site surveys and on historical-technical sources, grottoes can be regarded to be as one of the cause of increase of seismic effects on buildings in some quarters of the town, characterised by hundreds of man-made cavities dug in historical times.

The town examined here as test bed is Rionero in Vulture (Southern Italy) that was hit by several historical earthquakes among which the 1930 Irpinia earthquake.

Georadar investigation suggest that the underground of Rionero is crossed by cavities that not rarely exceed $10-12 \mathrm{~m}$. Geophysical investigations are of great importance in this context because most caves are abandoned and, therefore, they can not be surveyed.

Features of the grottoes suggest that more orders of caves are near and can statically and dynamically to interact. Moreover, caves not rarely are just below the foundation soils and they do not seem to show strengthening interventions.

All these considerations lead us to strongly suppose that underground voids played an important role in increasing the seismic damage by reducing the stability of the building foundation soils.

To better to corroborate this work hypothesis, the approach above indicated will be integrated by further geophysical investigations (georadar analysis with lower frequency antenna, geoelectrical surveys, ambient noise measurements) will allow to mitigate the seismic risk of the historical centre.

As above mentioned, the town considered here is characterised by hundreds of man-made cavities dug in historical times. These site conditions are common in several cities 
over the world, such as Mexico City, Nottingham, Catania, and Naples. Therefore, a similar methodological approach could be adopted in these sites, too.

Edited by: L. Eppelbaum, N. Masini, and F. Soldovieri

Reviewed by: two anonymous referees

\section{References}

Blindow, N., Erzenginger, P., Pahls, H., Scholz, H., and Thyssen, F.: Continuous profiling of subsurface structures and groundwater surface by EMR methods in Southern Egypt, Berliner Geowiss. Abh. (A), 75.2, 575-627, 1987.

Boschi, E., Guidoboni E., Ferrari G., Mariotti D., Valensise G. and Gasperini P. (Eds): Catalogue of Strong Italian Earthquakes from 461 B.C. to 1997, Ann. Geof. 43(4), with CD-ROM, 2000.

Brocchini, D., La Volpe, L., Laurenzi, M. A., and Principe, C.: Storia evolutiva del Monte Vulture, Plinius 12, 22-25, 1994.

Daniels, D. J.: Subsurface-penetrating radar. The Institution of Electrical Engineers, London, 1996.

Davis, J. L. and Annan, A. P.: Ground Penetrating Radar for high resolution mapping of soil and rock stratigraphy, Geophys. Prospect., 37, 531-551, 1989.

Giannandrea, P., La Volpe, P., Principe, C., and Schiattarella, M.: Unità stratigrafiche a limiti inconformi e storia evolutiva del vulcano medio-pleistocenico di Monte Vulture (Appennino meridionale, Italia), Boll. Soc. Geol. It., 125, 67-92, 2006.

Gizzi, F. T.: The electronic trading site eBay as a useful tool for obtaining historical data on natural events, Comput. Geosci., 9, 1950-1957, 2009.

Gizzi, F.T. and Masini, N.: Historical damage pattern and differential seismic effects in a town with ground cavities: A case study from Southern Italy, Eng. Geol., 88, 41-58, 2006.

Grünthal, G. (Ed.): European Macroseismic Scale 1998. Cahiers du Centre Européen de Géodynamique et de Séismologie, Luxembourg, 1998.

Lazzari, M., Geraldi, E., Lapenna, A., and Loperte, A.: Natural hazards vs human impact: an approach in geomorphological risk assessment on the Tursi historical site, Southern Italy, Landslides, 3(4), 275-287, 2006.

Lentini, F., Catalano, S., and Carbone, S.: The external thrust system in Southern Italy: a target for petroleum exploration, Petrol. Geosci., 2, 333-342, 1996.

Loperte, A., Cristallo, F., Lapenna, V., Bavusi M., Piscitelli S., and Rizzo, E.: GPR and Electrical tomography survey to detect cavities in the urban area of Matera (Southern Italy), Progress in Electromagnetic Research Symposium, 28-31 March 2004, Pisa, Italy.
Mochales, T., Casas, A. M., Pueyo, E. L., Pueyo, O., Román, M. T., Pocoví, A., Soriano, M. A., and Ansón, D.: Detection of underground cavities by combining gravity, magnetic and ground penetrating radar surveys: a case study from the Zaragoza area, NE Spain, Env. Geol., 53, 1067-1077, 2008.

Morey, R. M.: Continuous subsurface profiling by impulse radar, in: Proceedings of Conference on Subsurface Exploration for Underground Excavation and Heavy Construction, Am. Soc. Of Civil Engineers, Henniker, NH, 213-232, 1974.

Mostardini, F. and Merlini S.: Appennino centro-meridionale. Sezioni geologiche e proposta di modello strutturale, Mem. Soc. Geol. It., 35, 177-202, 1986.

Patacca, E. and Scandone, P.: Post-Tortonian mountain building in the Apennines. The role of the passive sinking of a relic lithospheric slab The lithosphere in Italy. Advances in Earth Science Research. Proc. It. Nat. Comm. Int. Lith. Progr. Mid-term Conf. (Rome, 5-6 May 1987), Accademia Nazionale dei Lincei, 80, 157-176, 1989.

Pescatore, T., Renda, P., Schiattarella, M., and Tramutoli, M.: Stratigraphic and structural relationship between Meso-Cenozoic Lagonegro basin and coeval carbonate platforms in southern Apennines, Italy, Tectonophysics, 315, 269-286, 1999.

Piscitelli, S., Rizzo, E., Cristallo, F., Lapenna, V., Crocco, L., Persico, R., and Soldovieri, F.: GPR and microwave tomography for detecting shallow cavities in the historical area of "Sassi of Matera” (Southern Italy), Near Surf. Geophys., 5, 275-284, 2007.

Sandmeier, K. J.: Program for Processing and Interpretation of Reflection and Transmission data, Karlsruha, Germany, 2001.

Scandone, P., Patacca, E., Meletti, C., Bellatalla,. M., Perilli, N., and Santini, U.: Struttura geologica, evoluzione cinematica e schema sismotettonico della penisola italiana Atti del Convegno Annuale del Gruppo Nazionale per la Difesa dai Terremoti (Pisa, 25-27 giugno 1990), 119-135, 1992.

Schiattarella, M., Beneduce, P., Di Leo, P., Giano, S. I., Giannandrea, P., and Principe, C.: Assetto strutturale ed evoluzione morfotettonica quaternaria del volcano del Monte Vulture (Appennino lucano), Boll. Soc. Geol. It., 124, 543-562, 2005.

Ulriksen, P.: Application of impulse Radar to Civil Engineering, Doctoral Thesis, Lund university of Technology, Dept. of Eng. Geol., Sweden. Coden: Lutvdg/(TVTTG-1001)/1-175, 1982.

Ulugergerli, E. U. and Akça, I.: Detection of cavities in gypsum, The Journal of the Balkan Geophysical Society, 9, 1, 8-19, 2006.

Wadhwa, R. S., Ghosh, N., Chandrasekhar V., and Sinharay, R. K.: Delineation of cavities in a canal by geophysical survey in Navargaon project area,Maharashtra, Journal of Indian Geophysical Union, 12(1), 55-62, 2008. 